\title{
Effect of Plant Spacing on Yield and Yield Contributing Traits of Black gram (Vigna mungo L. Hepper) During Autumn Season at Gokuleshwor, Baitadi, Nepal
}

\author{
Kailash Raman Bhatt* \\ Department of Agronomy, Gokuleshwor Agriculture and Animal Science College, \\ Baitadi, Nepal \\ *Corresponding Author: Kailash Raman Bhatt, Department of Agronomy, \\ Gokuleshwor Agriculture and Animal Science College, Baitadi, Nepal.
}

DOI: 10.31080/ASAG.2020.04.0804
Received: February 04, 2020

Published: February 17, 2020

(C) All rights are reserved by Kailash Raman

Bhatt.

\begin{abstract}
An experiment was carried out at the research field of Gokuleshwor Agriculture and Animal Science College Baitadi, Nepal from August 5, 2019, to November 10, 2019, to evaluate the impact of plant spacing on yield and yield contributing traits of black gram. The experiment was carried out at four levels of spacing viz. $\mathrm{T}_{1}(30 \times 5 \mathrm{~cm}), \mathrm{T}_{2}(30 \times 10 \mathrm{~cm}), \mathrm{T}_{3}(45 \times 10 \mathrm{~cm})$ and $\mathrm{T}_{4}(60 \times 10 \mathrm{~cm})$. The experiment was laid out in Randomized Complete Block Design having four replications. The differential plant spacing showed remarkable differences in yield and yield contributing traits of black gram cultivation practices at 0.05 level of significance. The highest plant spacing of $60 \times 10 \mathrm{~cm}$ performed better in yield contributing traits such as; number of branches plant ${ }^{-1}$, number of pods plant ${ }^{-1}$ and number of seeds pod $^{-1}$. Whereas, the maximum straw yield was found at closure spacing of $30 \times 5 \mathrm{~cm}$. Similarly, grain yield and harvest index were found superior at the spacing of $30 \times 10 \mathrm{~cm}$. Therefore, plant spacing of $30 \times 10 \mathrm{~cm}$ can be recommended to the farmers of Baitadi after confirming the results for a few years.
\end{abstract}

Keywords: Branches; Black gram; Harvest Index; Spacing; Yield

\section{Introduction}

Pulses are important protein sources for predominately vegetarian populations of our country. Besides various other legume crops, black gram (Vigna mungo L. Hepper) is one of the most important pulse crops of Nepal. It contains about 20 - 24\% protein, $1.2 \%$ fat and $56.6 \%$ carbohydrates on a dry weight basis and it is a rich source of calcium and iron. It differs from other pulses in its peculiarity of attaining a somewhat mucilaginous pasty character, giving additional body to the mass due to long polymer chain of polysaccharide chain of carbohydrate [1].

The economic product of black gram is grain, which is a good source of dietary protein. In Nepal, it is cultivated in 22,375 hectares of land and is produced 19,011 tons of grain with a productivity of $0.85 \mathrm{tha}^{-1}[2]$.
It is a prime necessity to maintain the optimum plant population by adjusting inter and intra row spacing properly. Maximum or minimum plant density may reduce the yield of black gram causing different physiological changes in the plant. Therefore, optimum row spacing plays an important role in contributing to the high yield because overcrowded plant population will not get proper light for photosynthesis and can easily be attacked by the various pests. Maintaining optimum plant population per unit area provides conditions such as, maximum light interception, photosynthetic activity, assimilation and accumulation of more photosynthates, which facilitates luxuriant crop growth and better plant canopy area and hence they produce higher seed yield and best yield quality traits [3]. Therefore, the present study was undertaken to evaluate the optimum plant population density by adjusting different inter and intra row spacing to increase the seed yield of black gram. 


\section{Material and Methods}

The experiment was carried out at the experimental field of Gokuleshwor Agriculture and Animal Science College (GAASC), Baitadi, Nepal during August 5, 2019, to November 10, 2019. The experimental site was located at 780 masl. The experiment was laid out in Randomized Complete Block Design with four replications, where treatment consists of four levels of spacing viz. $\mathrm{T}_{1}$ $(30 \mathrm{~cm} \times 5 \mathrm{~cm}), \mathrm{T}_{2}(30 \mathrm{~cm} \times 10 \mathrm{~cm}), \mathrm{T}_{3}(45 \mathrm{~cm} \times 10 \mathrm{~cm})$ and $\mathrm{T}_{4}(60$ $\mathrm{cm} \times 10 \mathrm{~cm}$ ). Kalu cultivar was used as an experimental material sown on August 5, 2019. The seeds were planted in ridges having a depth of $3 \mathrm{~cm}$ from the soil surface.

The manure and fertilizer were applied and mixed thoroughly each plot through organic manures and chemical fertilizers. Farm Yard Manure (FYM) was used as organic manure and Urea, Diammonium Phosphate (DAP) and Muriete of Potash (MOP) were applied during the final land preparation as sources of nitrogen, phosphorus, and potassium as inorganic sources. The recommended dose of Fertilizer for Black gram in Nepal is 20:40:20 $\mathrm{kg}$ NPK ha-1. Weeding and thinning were done manually as first weeding was carried out at 30 DAS and second at 45 DAS.

Harvesting was done when $80 \%$ of the pods turn from brown to black. Harvesting was carried out by pulling the whole plants and dried in the threshing floor for a week and threshing was done by beating by a stick. The seeds were separated and cleaned by winnowing and finally cleaned seeds are dried in sun for 3 days at $10 \%$ seed moisture. The growth parameters were collected and recorded from two selected rows of each treatment and yield and yield attributing data were collected and recorded from the middle three selected rows of each plot i.e., net plot area. The different parameters were statistically analyzed by the Gen STAT computer package program. The mean difference of yield and yield contributing traits were compared to DMRT (Duncan's Multiple Range Test) at $5 \%$ level of significance.

\section{Result and Discussion}

Number of branches plant ${ }^{-1}$

The number of branches per plant in blackgram was significantly affected by different levels of spacing as Table 1 . The number of branches was found significantly higher (4.98) at $\mathrm{T}_{3}(45 \times 10$ $\mathrm{cm})$ which was at par with the $\mathrm{T}_{4}(60 \times 10 \mathrm{~cm})$ and $\mathrm{T}_{2}(30 \times 10$ $\mathrm{cm})$ and that of lowest (2.68) at closed spacing i.e., $\mathrm{T}_{1}(30 \times 5 \mathrm{~cm})$.
Higher the number of branches in widest spacing was might be due to the interception of more solar radiation and less interspecific competition among plants. But, in narrow spaced plant showed overcrowding and did not have enough space for branching. Our results are similar to the Raman and Sinhamahapatra [4] who stated that, wider plant spacing which intercepted more photosynthetically active radiation owing to better geometric situation resulted in vigorous plant growth and more number of branches and leaves as compared to narrow spacing.

Bahadur and Singh [5] reported that, increase the number of branches in wider spaced rows was attributed due to more horizontal growth and plant canopy area due to less plant population density and other competitions compared to those in closer spacing.

\section{Number of pods plant ${ }^{-1}$}

The data on the number of pods per plant was highly influenced by different levels of spacing in Table 1 . The result reveals that, the significantly higher number of pods per plant (20.01) was found in the plots having distant spacing i.e., $\mathrm{T}_{4}(60 \times 10 \mathrm{~cm})$ followed by $\mathrm{T}_{3}(45 \times 10 \mathrm{~cm})$ and $\mathrm{T}_{2}(30 \times 10 \mathrm{~cm})$ and that of lowest (14.53) at $\mathrm{T}_{1}(30 \times 5 \mathrm{~cm})$. Higher pod numbers in the far spaced plots might be due to higher accumulation and assimilation food reserves and better source to sink relationship in wider spaced rows which might have adversely affected the pod development, hence, pods formation were comparatively higher than that of closely spaced rows.

The number of pods plant ${ }^{-1}$ increased and seed yield decreased with the increase in plant spacing. In contrast, optimum plant spacing of $30 \times 10 \mathrm{~cm}$ showed the highest harvest index and consequently produced higher seed yield. This indicates that the optimum plant spacing containing a reasonable number of plants per unit area with the optimum of pods plant ${ }^{-1}$ gave better seed yield [6].

\section{Number of seeds pod ${ }^{-1}$}

Data presenting in Table 1 showed that, the number of seeds per pod was significantly influenced by different levels of spacing. The Significantly higher number of seeds per pod (8.27) was found in $\mathrm{T}_{4}(60 \times 10 \mathrm{~cm})$ followed by $\mathrm{T}_{2}(30 \times 10 \mathrm{~cm})$ and $\mathrm{T}_{3}(45 \times 10$ $\mathrm{cm})$ and that of lowest $(5.77)$ at $\mathrm{T}_{1}(30 \times 5 \mathrm{~cm})$. It might be due to 
Effect of Plant Spacing on Yield and Yield Contributing Traits of Black gram (Vigna mungo L. Hepper) During Autumn Season at Gokuleshwor, Baitadi, Nepal

reduced competition and higher availability of growth resources leading to more space available for plants, lesser competition for moisture and nutrients between plants, hence, better grain filling which ultimately affects the number of seeds per pod. Decreased number of seeds pod $^{-1}$ under closer spacing was due to mortality caused by mutual shading during the pre-flowering stage of the crop. Similar findings were also reported by Siddaraju, Narayanaswamy, and Prasad [7] in cluster bean.

\begin{tabular}{|l|c|c|c|c|}
\hline Treatments & Spacing (cm) & $\begin{array}{c}\text { Number of } \\
\text { branches plant }\end{array}$ & $\begin{array}{c}\text { Number of pods } \\
\text { plant }^{-1}\end{array}$ & $\begin{array}{c}\text { Number of seeds } \\
\text { pod }^{-\mathbf{1}}\end{array}$ \\
\hline $\mathrm{T}_{1}$ & $30 \times 5$ & $2.68^{\mathrm{b}}$ & $14.53^{\mathrm{c}}$ & $5.77^{\mathrm{b}}$ \\
\hline $\mathrm{T}_{2}$ & $30 \times 10$ & $4.88^{\mathrm{a}}$ & $17.48^{\mathrm{b}}$ & $7.87^{\mathrm{a}}$ \\
\hline $\mathrm{T}_{3}$ & $45 \times 10$ & $4.98^{\mathrm{a}}$ & $17.49^{\mathrm{b}}$ & $7.25^{\mathrm{ab}}$ \\
\hline $\mathrm{T}_{4}$ & $60 \times 10$ & $4.93^{\mathrm{a}}$ & $20.01^{\mathrm{a}}$ & $8.27^{\mathrm{a}}$ \\
\hline $\mathrm{SEm}( \pm)$ & & 0.30 & 0.47 & 0.54 \\
\hline LSD $=0.05$ & & $0.96^{*}$ & $1.51^{* *}$ & $1.72^{*}$ \\
\hline CV, \% & & 13.9 & 5.5 & 14.8 \\
\hline Grand Mean & & 4.29 & 17.38 & 7.29 \\
\hline
\end{tabular}

Table 1: Number of branches plant ${ }^{-1}$, number of pods plant ${ }^{-1}$ and number of seeds pod ${ }^{-1}$ at harvest as influenced by spacing at GAASC farm, Baitadi in 2019.

Note: Means followed by common letter (s) within each column are not significantly different at $5 \%$ level of significance based on DMRT

\section{Straw yield ha-1}

Data regarding mean values of straw yield as influenced by the effect of row spacing. The table 2 revealed that maximum straw yield $\left(1.10 \mathrm{t} \mathrm{ha}^{-1}\right)$ was obtained by $\mathrm{T}_{1}(30 \times 5 \mathrm{~cm})$ which was statistically similar with $\mathrm{T}_{2}(30 \times 10 \mathrm{~cm})$ followed by $\mathrm{T}_{4}(60 \times 10$ $\mathrm{cm})$ and least at $\mathrm{T}_{3}(45 \times 10 \mathrm{~cm})$. Higher stover yield of blackgram at closed row spacing might be due to more population per unit area which contributed to more biomass and hence higher stover yield. Sathyamoorthi, Amanullah, Vaiyapuri and Somasundaram [8] were also found more stover yield in green gram with closer spacing, which could be attributed to higher population and accumulation of nutrients per unit area compared to wider spacing. Close row spacing improved dry matter yield compared with the far row spacing.

\section{Grain yield ha-1}

In respect of seed yield, the maximum seed yield (1.41 $\left.\mathrm{tha}^{-1}\right)$ was harvested in $\mathrm{T}_{2}(30 \times 10 \mathrm{~cm})$ followed by $\mathrm{T}_{1}(30 \times 5 \mathrm{~cm})$ and $\mathrm{T}_{3}$ $(45 \times 10 \mathrm{~cm})$ and least $\left(0.64 \mathrm{t} \mathrm{ha}^{-1}\right)$ at $\mathrm{T}_{4}(60 \times 10 \mathrm{~cm})$. Higher grain yield at closer spacing might be due to the higher plant population, there was an increase in the proportion of the number of pods produced more seed yield. Plants under optimum spacing would have effectively utilized the growth resources, particularly solar radiation as compared to plants under narrow spacing.

\begin{tabular}{|l|c|c|c|c|}
\hline Treatments & $\begin{array}{c}\text { Spacing } \\
\text { (cm) }\end{array}$ & $\begin{array}{c}\text { Straw yield } \\
\text { (t ha }^{-1} \text { ) }\end{array}$ & $\begin{array}{c}\text { Grain yield } \\
\mathbf{( t ~ h a}^{-1} \text { ) }\end{array}$ & $\begin{array}{c}\text { Harvest } \\
\text { index } \\
\text { (HI) }\end{array}$ \\
\hline $\mathrm{T}_{1}$ & $30 \times 5$ & $1.10^{\mathrm{a}}$ & $0.85^{\mathrm{b}}$ & $0.44^{\mathrm{b}}$ \\
\hline $\mathrm{T}_{2}$ & $30 \times 10$ & $1.01^{\mathrm{a}}$ & $1.41^{\mathrm{a}}$ & $0.59^{\mathrm{a}}$ \\
\hline $\mathrm{T}_{3}$ & $45 \times 10$ & $0.54^{\mathrm{b}}$ & $0.76^{\mathrm{b}}$ & $0.58^{\mathrm{a}}$ \\
\hline $\mathrm{T}_{4}$ & $60 \times 10$ & $0.66^{\mathrm{b}}$ & $0.64^{\mathrm{b}}$ & $0.48^{\mathrm{b}}$ \\
\hline $\mathrm{SEm}( \pm)$ & & 0.10 & 0.13 & 0.02 \\
\hline LSD $=0.05$ & & $0.33^{*}$ & $0.42^{*}$ & $0.09^{*}$ \\
\hline $\mathrm{CV}, \%$ & & 25.1 & 28.7 & 11.1 \\
\hline Grand Mean & & 0.83 & 0.92 & 0.52 \\
\hline
\end{tabular}

Table 2: Straw yield, grain yield and harvest index as influenced by spacing at GAASC farm, Baitadi in 2019.

Note: Means followed by common letter (s) within each column are not significantly different at $5 \%$ level of significance based on DMRT 
Ganiger, Kareekaatti, and Patil [9] reported that optimum plant population, spacing and proper management of weed showed higher seed yield of blackgram. This could be due to enhanced vegetative growth and lesser yield attributes owing to severe competition between plants. Kabir and Sarkar [10] also reported that spacing of $30 \times 10 \mathrm{~cm}$ gave the highest number of pods per plant, the highest grain yield, and the highest stover yield.

\section{Harvest index}

Harvest index (HI) is an important physiological character of the plants that reflect dry matter partitioning to their economic parts. The harvest index of blackgram was significantly affected by different levels of spacing as Table 2. Maximum HI (0.59) was obtained by $\mathrm{T}_{2}(30 \times 10 \mathrm{~cm})$ which was statistically at par with $\mathrm{T}_{3}(45 \times 10 \mathrm{~cm})$ followed by $\mathrm{T}_{4}(60 \times 10 \mathrm{~cm})$ and least $(0.44)$ was found at $\mathrm{T}_{1}(30 \times 5 \mathrm{~cm})$. Achakzai and Panizai [11] also found similar findings in their research and stated that maximum $\mathrm{HI}$ of 0.61 was got in row spacing of $40 \mathrm{~cm}$, which is statistically at par with four other spacing viz; 20, 25, 30 and $35 \mathrm{~cm}$.

\section{Conclusion}

The variation in yield and yield contributing traits of black gram was observed due to different levels of plant spacing. The yield contributing traits were found superior at the spacing of $60 \times 10 \mathrm{~cm}$ while straw yield was increasing with decreasing the plant spacing. Maintaining the plant the spacing of $30 \times 10 \mathrm{~cm}$ was found promising and gave better seed yield and harvest index of crop.

\section{Bibliography}

1. Zia-Ul-Haq M., et al. "Compositional studies of some pea (Pisum sativum L.) seed cultivars commonly consumed in Pakistan". Italian Journal of Food Science 25.3 (2013).

2. MoAD. Statistical information on Nepalese agriculture. Government of Nepal, Ministry of Agricultural Development, Agristatistics section, Singha Durbar, Kathmandu, Nepal (2019).

3. Mozumder SN., et al. "Influence of support systems and spacing on hyacinth bean production in the eastern hilly area of Bangladesh". Legume Research-An International Journal 30 (2007): 1-9.

4. Raman RB and Sinhamahapatra SP. "A dwarf determinate plant type for achieving higher and stable yield in blackgram (Vigna mungo L. Hepper)". The Bioscan 9.2 (2014): 497-500.
5. Bahadur A and Singh KP. "Optimization of spacing and drip irrigation scheduling in indeterminate tomato (Lycopersicon esculentum)". Indian Journal of Agricultural Science 75.9 (2005): 563-565.

6. Asaduzzaman M., et al. "Weeding and plant spacing effects on the growth and yield of blackgram". Bangladesh Research Publication Journal 4.1 (2010): 62-68.

7. Siddaraju R., et al. "Studies on growth, seed yield and yield attributes as influenced by varieties and row spacing in cluster bean (Cyamopsis tetragonoloba L.)". Mysore Journal of Agricultural Sciences 44.1 (2010): 16-21.

8. Sathyamoorthi K., et al. "Physiological parameters and yield of greengram (Vigna radiata L.) Wilczek as influenced by increased plant density and fertilizer levels". Indian Journal of Crop Science 3.1 (2008): 115-122.

9. Ganiger TS., et al. "Economics use of plant growth characters and yield performance of cowpea". Karnataka Journal of Agricultural Sciences 16.1 (2003)" 35-38.

10. Kabir MH and Sarkar MAR. "Seed yield of mungbean as affected by variety and plant spacing in Kharif-I season". Journal of the Bangladesh Agricultural University 6 (2018).

11. Achakzai AKK and Panizai K. "Effect of row spacing on growth, yield and yield components of mashbean". Sarhad Journal of Agriculture 23.1 (2007): 5.

\section{Assets from publication with us}

- Prompt Acknowledgement after receiving the article

- Thorough Double blinded peer review

- Rapid Publication

- Issue of Publication Certificate

- High visibility of your Published work

Website: www.actascientific.com/

Submit Article: www.actascientific.com/submission.php Email us: editor@actascientific.com

Contact us: +919182824667 